\title{
Responses of phytoplankton and Pfiesteria-like dinoflagellate zoospores to nutrient enrichment in the Neuse River Estuary, North Carolina, USA
}

\author{
James L. Pinckney ${ }^{1, *}$, Hans W. Paerl ${ }^{2}$, Elin Haugen ${ }^{3}$, Patricia A. Tester ${ }^{3}$ \\ ${ }^{1}$ Department of Oceanography, Texas A\&M University, College Station, Texas 77843-3146, USA \\ ${ }^{2}$ University of North Carolina at Chapel Hill, Institute of Marine Sciences, 3431 Arendell Street, Morehead City, \\ North Carolina 28557, USA \\ ${ }^{3}$ National Ocean Service, NOAA, Center for Coastal Fisheries and Habitat Research at Beaufort, 101 Pivers Island Road, \\ Beaufort, North Carolina 28516, USA
}

\begin{abstract}
The recently described toxic dinoflagellate Pfiesteria piscicida and morphologically similar Pfiesteria-like dinoflagellates have become a major water quality issue with possible fish mortality and reported human health implications. The linkages between accelerated nutrient loading, eutrophication, and the proliferation of this group of dinoflagellates, however, are not well established for natural systems. Phytoplankton primary production may provide a key link between nutrient inputs and potential outbreaks of Pfiesteria-like biflagellated zoospores in the Neuse River Estuary, North Carolina. The impacts of nutrient $\left(\mathrm{NO}_{3}{ }^{-}\right.$-nitrogen and $\mathrm{PO}_{4}{ }^{3-}$-phosphorus) supply rates, sediment-water column exchange, water column mixing, and phytoplankton prey on the abundance of Pfiesteria-like non-toxic biflagellated zoospores were examined seasonally over 18 mo in a region of the Neuse River Estuary where fish-kills attributed to $P$. piscicida have been reported. Phytoplankton community responses to the manipulated variables indicated that biomass and productivity were consistently $N$ limited. Dominant phytoplankton taxa, including chlorophytes, diatoms, and cyanobacteria, exhibited significant biomass increases in response to $\mathrm{N}$ (as $\mathrm{NO}_{3}{ }^{-}$) additions. Phosphate (as $\mathrm{PO}_{4}{ }^{3-}$ ) enrichments did not additionally influence the relative growth and abundance of individual algal groups. Pfiesterialike zoospores did not exhibit significant increases in abundance in response to mixing, sediment, or nutrient-addition treatments. Seasonally, the number of Pfiesteria-like zoospores was positively correlated with phytoplankton biomass and productivity. The abundance of Pfiesteria-like zoospores followed general trends in phytoplankton biomass and production in the estuary, suggesting that the source of organic nutrition supporting growth is likely phytoplankton based. Lowering of phytoplankton growth and bloom potentials through proposed nutrient-input reduction strategies should translate into broad-based water quality improvement, including declines in the frequency and magnitudes of nuisance algal blooms, $\mathrm{O}_{2}$ depletion, and associated fish and shellfish mortality in the Neuse River Estuary.
\end{abstract}

KEY WORDS: Phytoplankton · Mesocosm - Growth - Nutrient · Estuary - North Carolina

\section{INTRODUCTION}

The recent description of Pfiesteria piscicida Steidinger et Burkholder (Steidinger et al. 1996a) and 'look-alike' dinoflagellates (Landsberg et al. 1995, Burkholder \& Glasgow 1997b) capable of killing fish in laboratory experiments (Lewitus et al. 1995, Noga et al.

•E-mail: pinckney@ocean.tamu,edu
1996, Burkholder \& Glasgow 1997b) has heightened concerns about potentially adverse environmental and human health impacts (Glasgow et al. 1995). So far, Pfiesteria-like dinoflagellates have been detected in estuarine waters ranging from Florida to Maryland along the eastern US Atlantic coast (Lewitus et al. 1995, Burkholder \& Glasgow 1997b). In laboratory aquaria, non-toxic stages exposed to fish and fish excreta for extended periods (days) undergo transformation to a 
toxic form, kill fish, and within hours disappear from the water column (encyst and settle to the sediment) (Burkholder \& Glasgow 1995, Burkholder et al. 1995a, Lewitus et al. 1995). Research efforts have concentrated on dinoflagellate-fish interactions in waters experiencing fish-kills and the potential detrimental impacts on fish in nature (Burkholder et al. 1995b, Glasgow et al. 1995, Lewitus et al. 1995, Noga et al. 1996). The toxic biflagellated vegetative stages are considered transitory, while the non-toxic stage appears to be the commonly encountered zoospore in nature (Burkholder \& Glasgow 1995, Steidinger et al. 1996a, Steidinger \& Tangen 1997). Although most of the previous research and attention have focused on the toxic stages, the factors controlling the population dynamics of non-toxic zoospore stages in nature may be most important for understanding environmental regulation of the overall abundance of Pfiesteria-like dinoflagellates

Pfiesteria piscicida belongs to a group of heterotrophic dinoflagellates that do not synthesize photopigments (i.e. chlorophylls and carotenoids) and rely on external food sources. Like many non-photosynthetic dinoflagellates, $P$. piscicida may supplement its nutritional requirements using photosynthate produced by chloroplasts captured from algal prey and sequestered in vacuoles (cleptochloroplasty) (Fields \& Rhodes 1991, Burkholder \& Glasgow 1995, 1997a, Steidinger et al. 1996a). The primary food source for the non-toxic biflagellated zoospore stage is phytoplankton (Burkholder \& Glasgow 1995, Burkholder et al. 1995b). However, little is known about the trophic linkage between the zoospore and its diet in natural settings. Factors that directly affect phytoplankton biomass and species composition (nutrients, mixing, light, etc.) may therefore indirectly affect the relative abundance of $P$. piscicida. In this regard, it has been suggested that nutrients supporting phytoplankton growth may play a role in the growth and proliferation of $P$. piscicida and Pfiesterialike species (Burkholder et al. 1992, Burkholder \& Glasgow 1995, Glasgow et al. 1995). This possibility merits consideration because a link between nutrient enrichment and accelerated phytoplankton production (eutrophication) has been proposed in many estuaries in which Pfiesteria-like cells have been reported (Burkholder \& Glasgow 1997 b).

During the past 2 decades, alarming symptoms of eutrophication, including nuisance cyanobacterial, cryptomonad, and dinoflagellate blooms, associated bottom water hypoxia/anoxia, fish-kills, and altered food web structure have plagued water quality in the lower Neuse River Estuary, North Carolina (Fig. 1) (Paerl 1983, 1987, Christian et al. 1986, Paerl et al. 1998). Primary production is controlled by $N$ availability (i.e. is $\mathrm{N}$ limited) throughout much of the year (Paerl 1987. Boyer et al. 1994, Paerl et al. 1995). During the past $5 \mathrm{yr}$, the mesohaline segment of the estuary between New Bern and the entrance to Pamlico Sound has exhibited extensive winter-spring blooms of the dinoflagellates Heterocapsa triquetra and Gymnodinium minutum, and the cryptomonad Cryptomonas sp. (Mallin 1994, Pinckney et al. 1998) which have been attributed to enhanced $\mathrm{N}$ loading (Rudek et al. 1991, Mallin et al. 1993, Paerl et al. 1995). The primary research goals were to determine the potential regulatory roles of inorganic nutrient ( $N$ and $P$ ) enrichment, sediments (as a source cysts and amoebae), and water column mixing on the dynamics of natural phytoplankton communities including Pfiesteria-like biflagellated zoospores.

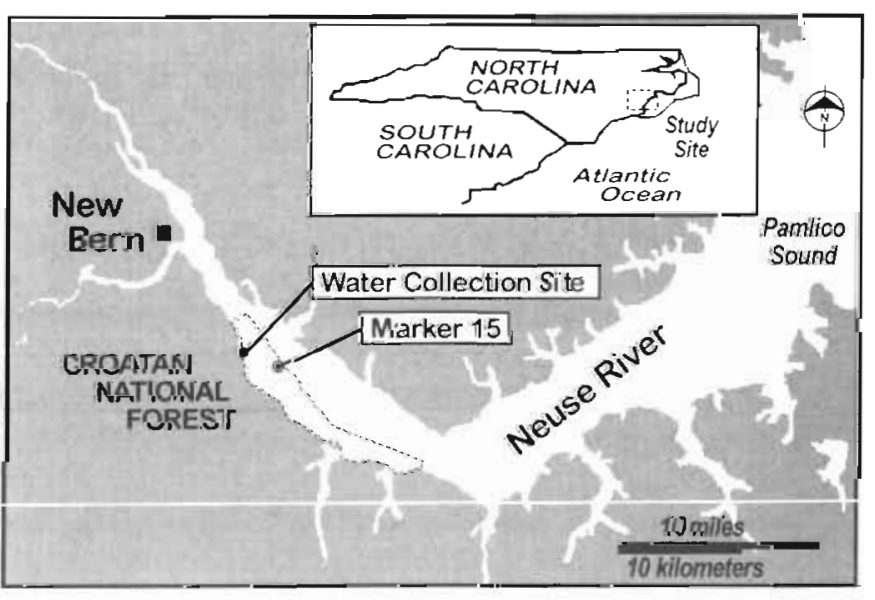

Fig. 1. Map of the lower Neuse River Estuary showing the location of the water collection site and water quality monitoring site (Marker 15). Dashed line shows the region of persistent fish kills since 1991

\section{MATERIALS AND METHODS}

Water collection. Bulk water for all mesocosm bioassays was collected from $1 \mathrm{~m}$ depth along the southwestern shore $\left(35.08^{\circ} \mathrm{N}, 77.00^{\circ} \mathrm{W}\right)$ of the Neuse River between Cherry Point and New Bern, North Carolina (Fig. 1). This estuary experienced large fish-kills in 1991 and 1995 to 1998 , reported to be associated with Pfiesteria-like dinoflagellates (Burkholder \& Glasgow 1997 b) Water was pumped into a pre-cleaned (flushed with river water) trailer-mounted 45001 (incet polycthylenc) tunk using ô non-destructive diaphragm pump (Miller \& Judkins 1981) and transported to the Institute of Marine Sciences (IMS). Bulk water from the trailer tank was administered (within 2 h of collection) to 36 translucent $185 \%$ PAR transmittance) fiberglass tanks (55 1) arranged in a concrete pond at IMS. The 
pond was filled with seawater from the adjacent Bogue Sound for temperature and light control.

Mesocosm experimental design. The purpose of these experiments was to provide a range of potential phytoplankton prey species, biomass, and environmental conditions to determine their effects on the abundance of Pfiesteria-like zoospores. Tanks were assigned to 12 replicated treatment groups using a random number table (Table 1). Mixing was achieved by a gentle air stream flowing from a small pipe in the bottom of the tank. Benthic sediments were added to half the mesocosm tanks to provide a potential source for Pfiesteria-like zoospore precursor stages (cysts, amoebae). Sediment additions consisted of surface sediments (upper $3 \mathrm{~cm}$ ) from a water depth of $1.5 \mathrm{~m}$ at the water collection site in the Neuse River Estuary. Nutrient enrichments $\left(10 \mu \mathrm{M} \mathrm{NO}_{3}{ }^{-}\right.$and $3 \mu \mathrm{M} \mathrm{PO}_{4}{ }^{3-}$, final concentrations), reflecting concentrations commoniy encountered in the estuary, were administered as daily additions to the respective treatments in the early morning (08:00 h) on specified days (Table 2).

For statistical analyses, responses to the manipulated factors were analyzed using a general linear model (GLM) repeated measures analysis of variance (ANOVA) with 3 fixed factors (mixing, sediment, nutrients) and 3 replicates for each combination (Neter et al. 1985). Each tank was treated as a single case with repeated measures at fixed times. Time intervals for repeated measures consisted of Days $0,1,2,3$ and 6 for primary productivity; Days 0, 1, 3, and 6 for photopigments; and Days 0 and 3 or 6 for Pfiesteria-like cell counts. All data were ln-transformed before analysis to satisfy the normality assumption. Equality of error variances was checked using Levene's test (Neter et al. 1985). A Type IV sums of squares method was used because of missing data for some time points. The Games-Howell test $(\alpha=0.05)$ was used for post hoc multiple comparisons of means for factors without significant interaction terms (Neter et al. 1985).

Table 1. Experimental design for mesocosm bioassays

\begin{tabular}{|lllc|}
\hline Factor & Level & Description & Units \\
\hline Mixing & Static & No mixing & 18 tanks \\
& Mixed & Bubbled air & 18 tanks \\
Sediment & None & & 18 tanks \\
& Addition & $750 \mathrm{ml}$ sediment tank & 18 tanks \\
Nutrient & Control & No nutrients added & 12 tanks \\
& Nitrate & $10 \mu \mathrm{NO}_{3}^{-}$as $\mathrm{KNO}_{3}$ & 12 tanks \\
& Nitrate + & $10 \mu \mathrm{NO}_{3}-$ as $\mathrm{KNO}_{3}$ & \\
& Phosphate & $3 \mu \mathrm{MOO}_{4}{ }^{3-}$ as $\mathrm{KH}_{2} \mathrm{PO}_{4}$ & 12 tanks \\
\hline
\end{tabular}

Physical measurements. Salinity, specific conductivity, temperature, $\mathrm{pH}_{\text {, }}$ and dissolved oxygen measurements were obtained near noontime at the surface ( $0.25 \mathrm{~m}$ below) and bottom (0.25 $\mathrm{m}$ above) of each tank using a Hydrolab $\mathrm{H} 20$ water quality monitor. Biweekly to weekly surveys of water column properties were obtained at a fixed site in the Neuse River (Navigation Marker $15 ; 35.014^{\circ} \mathrm{N}, 76.960^{\circ} \mathrm{W}$ ) near the mesocosm water collection site (Fig. 1). Vertical profiles of conductivity, salinity, temperature, dissolved $\mathrm{O}_{2}$, and $\mathrm{pH}$ at $0.5 \mathrm{~m}$ intervals were obtained with the Hydrolab H20 water quality monitor. Water samples were collected near the water surface $(0.5 \mathrm{~m}$ depth) and at depth $(0.5 \mathrm{~m}$ from the bottom), transferred to acidcleaned, 20 l carboys, and kept cool and shaded during transport to the laboratory. Subsamples for nutrient and photopigment analyses were removed from bulk water samples within $3 \mathrm{~h}$ of collection.

Nutrient analyses. Water samples $(50$ to $100 \mathrm{ml})$ were filtered through pre-combusted (500\% C, $16 \mathrm{~h}), 25 \mathrm{~mm}$ glass-fiber filters (Whatman GF/F) before chemical analyses. Nitrite + nitrate $\left(\mathrm{NO}_{\mathrm{x}}{ }^{-} ; \mathrm{NO}_{2}{ }^{-}+\mathrm{NO}_{3}{ }^{-}\right)$, ammonium $\left(\mathrm{NH}_{4}{ }^{+}\right)$, and dissolved inorganic phosphate $\left(\mathrm{PO}_{4}{ }^{-3}\right)$ were quantified with a Lachat AutoAnalyzer (Quikchem 8000) using standard protocols (Lachat Quikchem methods 31-107-04-1-C, 31-107-06-1-A, 31-11501-3-C, respectively).

Phytoplankton photopigments. Chlorophylls and carotenoids were identified and quantified using high performance liquid chromatography (HPLC) (Millie et al. 1993, Tester et al. 1995, Jeffrey et al. 1997). Aliquots $(0.3$ to 11$)$ of water were filtered under a gentle vacuum (<50 kPa) onto $4.7 \mathrm{~cm}$ diameter GF/F filters, immediately frozen, and stored at $-80^{\circ} \mathrm{C}$. Frozen filters were placed in $100 \%$ acetone $(3 \mathrm{ml})$, sonicated, and extracted at $-20^{\circ} \mathrm{C}$ for 12 to $20 \mathrm{~h}$. Filtered extracts $(200 \mu l)$ were injected into a Spectra-Physics HPLC equipped with a single monomeric (Rainin MicrosorbMV, $0.46 \times 10 \mathrm{~cm}, 3 \mathrm{~mm}$ ) and 2 polymeric (Vydac $201 \mathrm{TP}, 0.46 \times 25 \mathrm{~cm}, 5 \mathrm{~mm}$ ) reverse-phase $C_{18}$ columns in series. This column configuration was devised to enhance the separation of similar photopigments and 

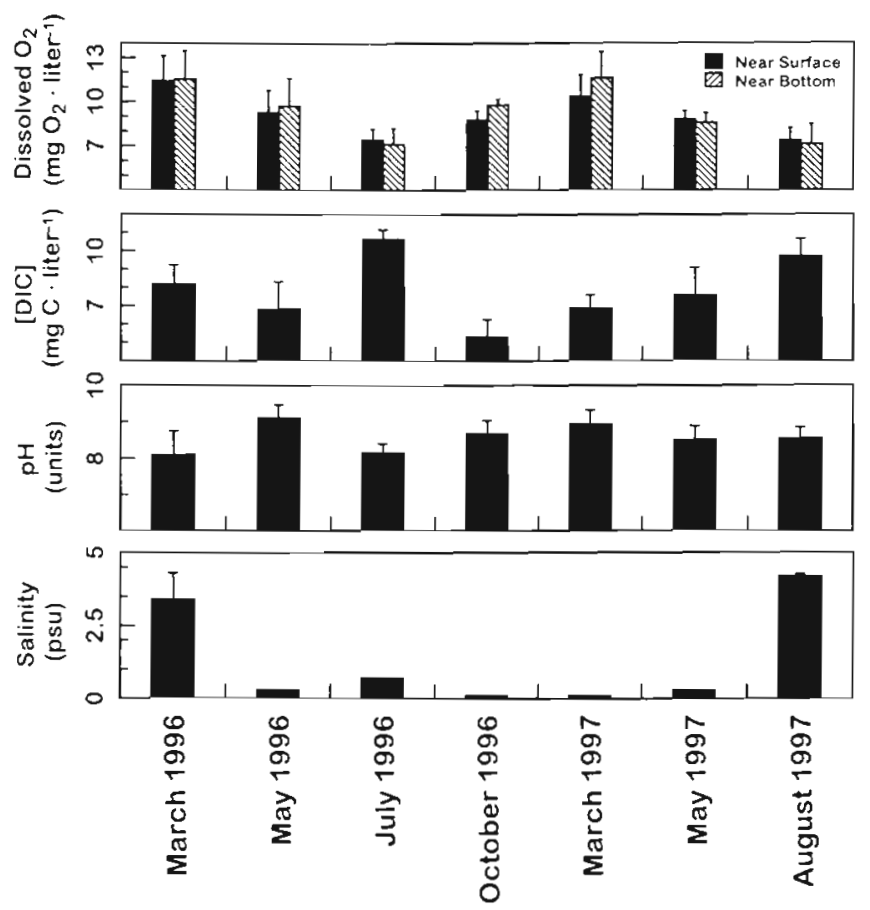

Fig. 2. Means $\left( \pm 1\right.$ SD) for dissolved oxygen $\left(\mathrm{O}_{2}\right)$, dissolved inorganic carbon $([\mathrm{DIC}]), \mathrm{pH}$, and salinity for all mesocosm tanks combined for the $6 \mathrm{~d}$ incubation periods

degradation products. Monomeric columns provide strong retention and high efficiency, while polymeric columns select for similar compounds with minor differences in molecular structure and shape (van Heukelem et al. 1994, Jeffrey et al. 1997). A non-linear binary gradient, adapted from van Heukelem et al. (1994), was used for pigment separations (for details, see Pinckney et al. 1996). Solvent A consisted of $80 \%$ methanol: $20 \%$ ammonium acetate $(0.5 \mathrm{M}$ adjusted to $\mathrm{pH} 7.2)$ and Solvent B was $80 \%$ methanol: $20 \%$ acetone. Absorption spectra and chromatograms (440 nm) were acquired using a Shimadzu SPD-M10av photodiode array detector. Pigment peaks were identified by comparison of retention times and absorption spectra with pure crystalline standards, including chlorophylls $a, b, \beta$-carotene (Sigma Chemical Company), fucoxanthin, and zeaxanthin (Hoffman-LaRoche and Company). Other pigments were identified by comparison to extracts from phytoplankton cultures (Wright et al. $1991)$ and quantified using the appropriate extinction coefficients (Mantoura \& Llewellyn 1983, Rowan 1989, Teffrey et al 1997). The presence of taxonomic groups as indicated by photopigment profiles was confirmed by qualitative microscopy.

Phytoplankton productivity. A single subsample (150 ml) of water was collected from mid-depth of each mesocosm tank and dispensed in clear polycarbonate bottles for phytoplankton primary productivity mea- surements. In addition, subsamples from 12 tanks were randomly selected for determination of dark uptake rates. Samples were injected with $\mathrm{NaH}^{14} \mathrm{CO}_{3}$ (185 to $260 \mathrm{kBq} \mathrm{ml}^{-1}$ final activity) and incubated in respective mesocosm tanks. Productivity incubations of 3 to $4 \mathrm{~h}$ (centered around local noon) were performed for each tank. After incubation, phytoplankton were filtered onto $25 \mathrm{~mm}$ GF/F filters, air dried, and fumed with concentrated $\mathrm{HCl}$ to remove unincorporated ${ }^{14} \mathrm{C}$. Filters were then placed in vials containing scintillation cocktail (Ecolume, ICN, Inc.) and the counts per minute (CPM) enumerated with a Beckman model LS5000TD liquid scintillation counter CPM were converted to disintegrations per minute (DPM) using quench curves constructed from a calibrated ${ }^{14} \mathrm{C}$-toluene standard. Dissolved inorganic carbon in water samples was determined by infrared gas analysis (Beckman model 864 IRGA) (Paerl 1987).

Pfiesteria taxonomy. Several species of small armored dinoflagellates $(5$ to $20 \mu \mathrm{m})$ are known to cooccur at fish-kill sites (Burkholder \& Glasgow 1997b). Some of these dinoflagellates are heterotrophic and polymorphic with thin thecal plates (lightly armored) and may be ichthyotoxic. The nature of the toxins and toxicity of these 'look-alikes' is unclear at this time (Burkholder \& Glasgow 1997b). Although these small dinoflagellates resemble Pfiesteria piscicida, they cannot be distinguished from $P$. piscicida using a light microscope (Landsberg et al. 1995, Steidinger et al. 1996a). Currently, scanning electron microscopy (SEM) is the only method available to definitively identify these small dinoflagellates and distinguish them from $P$. piscicida (Steidinger et al. 1996a,b. Truby 1997). In the present study, biflagellated zoospores of heterotrophic dinoflagellates that could not be distinguished from $P$ piscicida using light microscopy were counted and identified as Pfiesteria-like cells. Therefore cell counts reported in the present study are likely upper estimates of the actual abundance of $P$. piscicida zoospores.

Cell counts and culturing. Water samples for cell counts were collected from each mesocosm tank, preserved with an acetate-buffered Lugol's solution (Utermöhl 1958), and stored at $4^{\circ} \mathrm{C}$. Enumerations were undertaken for 24 of the 36 tanks in each experiment and included 2 replicates for each of the experimental manipulations. Subsamples of 5 to $25 \mathrm{ml}$ were settled in $25 \mathrm{ml}$ Hydrobios settling chambers for a minimum of 12 h to quantify Pfiesteria-like dinoflagellates using the

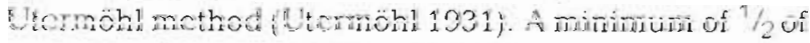
each chamber was examined on an aus Jena Sedival inverted microscope $(300 \times)$ to quantify cells. Standard light optics assisted in the location and identification of the colorless dinoflagellate in the iodine-staining preservative. Celis were not readily distinguishable for counting purposes with phase-contrast optics (P. Tester 
pers. obs.). Pfiesteria-like cell counts were based on enumerations of the dinoflagellate biflagellated zoospore stage that appeared consistent with those reported for $P$. piscicida at the light microscope level.

Enrichment protocols were used to establish monocultures of Pfiesteria-like zoospores from water collected from the Neuse River mesocosms (Litaker \& Tester unpubl.). Pfiesteria-like zoospores exhibited typical growth rates of 1 division $\mathrm{d}^{-1}$ under culture conditions. Seven cultures, obtained from representative mesocosm bioassay dates, were used for SEM analyses and species identification.

SEM preparations and species identification. Culture isolates of Pfiesteria-like biflagellated zoospores from each of the 7 mesocosm bioassays were sent to Dr Richard G. Zingmark (University of South Carolina, Columbia, SC) for species identification using SEM. Samples were prepared for SEM using the protocols outlined by Truby (1997). Briefly, the technique involves removing the outer membrane (amphiesma) using an ethanol dehydration series to expose the cell plates (theca). Samples were then fixed with a glutaraldehyde and osmium tetroxide fixative adjusted to the proper osmolality and critical-point-dried. SEM micrographs were obtained at $4000 \times$ to $10000 \times$, and plate counts determined after examining several cells in different orientations. The plate counts for all mesocosm isolates were identical, but did not match the published plate counts for $P$. piscicida (Steidinger et al. 1996a). K. Steidinger (Florida Institute of Marine Research, St. Petersburg, FL) has examined the Pfiesteria-like cell found in our samples and compared it with other, previously reported 'look-alike' dinoflagellates (Landsberg et al. 1995, Burkholder \& Glasgow 1997 b). The Pfiesteria-like cells cultured in the current study were a 'peridiniopsoid' to be placed in a new genus (Cryptoperidiniopsis nov. gen.; K. Steidinger pers. comm.). This peridiniopsoid dinoflagellate has 5 apical, 6 precingular, and no anterior intercalary plates (Po, cp, X, 5',0a, 6", 6?c, 4s, 5"',0p, and 2" ") differing from the tabulation for $P$. piscicida ( $\mathrm{Po}, \mathrm{cp}, \mathrm{X}, 4^{\prime}$, 1a, 5", 6c, 4s, 5"', 0p, and 2" ") (Steidinger et al. 1996a). Cryptoperidiniopsis sp. has been isolated from known fish-kill sites in the Pamlico and Neuse Rivers and has been identified from fish-kill areas in Maryland and from a fish-lesion area in northeast Florida (Burkholder \& Glasgow 1997b, K. Steidinger pers. comm.).

\section{RESULTS}

\section{Incubation conditions}

Mesocosm bioassay experiments were conducted on 7 occasions from March 1996 to August 1997 (Table 2).
The salinity of water in the mesocosm tanks ranged from 0.1 to 5.2 psu during the experimental period, and mean salinities varied depending on incubation dates (Fig. 2). Salinities were similar $( \pm 1 \mathrm{SD}<0.9)$ between tanks for each bioassay. The $\mathrm{pH}$ ranged from 7.42 to 9.66 but was generally between 8 and 9 for all experiments (Fig. 2). Total dissolved inorganic carbon (DIC) fluctuated between tanks and experiments, reflecting inorganic carbon uptake and phytoplankton productivity (Fig. 2). Dissolved oxygen $\left(\mathrm{O}_{2}\right)$ concentrations were near saturation in all tanks throughout the experimental period (Fig. 2). Mean surface $(0.25 \mathrm{~m}$ below surface) values ranged from 7.37 to 11.44 and bottom values $(0.25 \mathrm{~m}$ above bottom) ranged from 7.13 to $11.63 \mathrm{mg} \mathrm{O}_{2} \mathrm{l}^{-1}$. Surface and bottom $\mathrm{O}_{2}$ concentrations in the static (non-mixed) mesocosms were compared using a paired samples t-test to determine if mixing state affected $\mathrm{O}_{2}$ distributions. Without mixing, bottom water $\mathrm{O}_{2}$ concentrations were significantly higher than near surface values for both sediment $(N=265, p<$ $0.01)$ and no sediment treatments $(\mathrm{N}=268, p<0.01)$. However, the mean difference between surface and bottom $\mathrm{O}_{2}$ was $<0.5 \mathrm{mg} \mathrm{O}_{2} \mathrm{I}^{-1}$ for all static tanks. Surveys of dissolved $\mathrm{O}_{2}$ in the early morning (just after sunrise) indicated that tanks were not hypoxic/anoxic at night. Incubation conditions were compared with in situ conditions in the Neuse River Estuary during the study period (Fig. 3). Nutrient amendments to the mesocosm tanks reflected realistic $\mathrm{NO}_{x}{ }^{-}$and $\mathrm{PO}_{4}{ }^{3-}$ concentrations likely encountered by phytoplankton communities in this region of the Neuse Estuary during the study period.

\section{Phytoplankton biomass and productivity}

The summary results of the repeated measures ANOVA analyses were combined for all 7 bioassays (Table 3). Although 2-way and 3-way interaction terms were computed, no significant interactions were detected $(p<0.05)$. Significant effects for the nutrient treatments (no addition control, $\mathrm{NO}_{3}{ }^{-}$addition, and $\mathrm{NO}_{3}{ }^{-}+\mathrm{PO}_{4}{ }^{3-}$ addition) were further analyzed using the Games-Howell procedure to detect significant differences between treatment means (Table 3). Phytoplankton biomass (chl a) increases were significantly higher in mixed tanks in comparison with static (unmixed) treatments (Table 3, Fig. 4). The $\mathrm{NO}_{3}{ }^{-}$and $\mathrm{NO}_{3}{ }^{-}+\mathrm{PO}_{4}{ }^{3-}$ additions resulted in significantly higher chl a than unamended control treatments. However, chl a concentrations for the $\mathrm{NO}_{3}{ }^{-}+\mathrm{PO}_{4}{ }^{3-}$ additions were not significantly different from the $\mathrm{NO}_{3}^{-}$additions. Phytoplankton primary productivity was higher in the mixed tanks than the static tanks (Table 3 , Fig. 5). No significant differences in productivity were 
detected for the sediment versus no sediment treatments. Nitrate-amended tanks had a higher productivity than non-amended control tanks. In general, both biomass and productivity peaked within $2 \mathrm{~d}$ of the last nutrient addition and declined for the remainder of the incubation period. Collectively, the phytoplankton biomass and productivity results indicate that $\mathrm{N}$ was consistently the limiting nutrient for phytoplankton growth and productivity. Mixed treatments resulted in significantly higher biomass and productivity while sediment additions had no measurable effects on the phytoplankton community as a whole. Phytoplankton
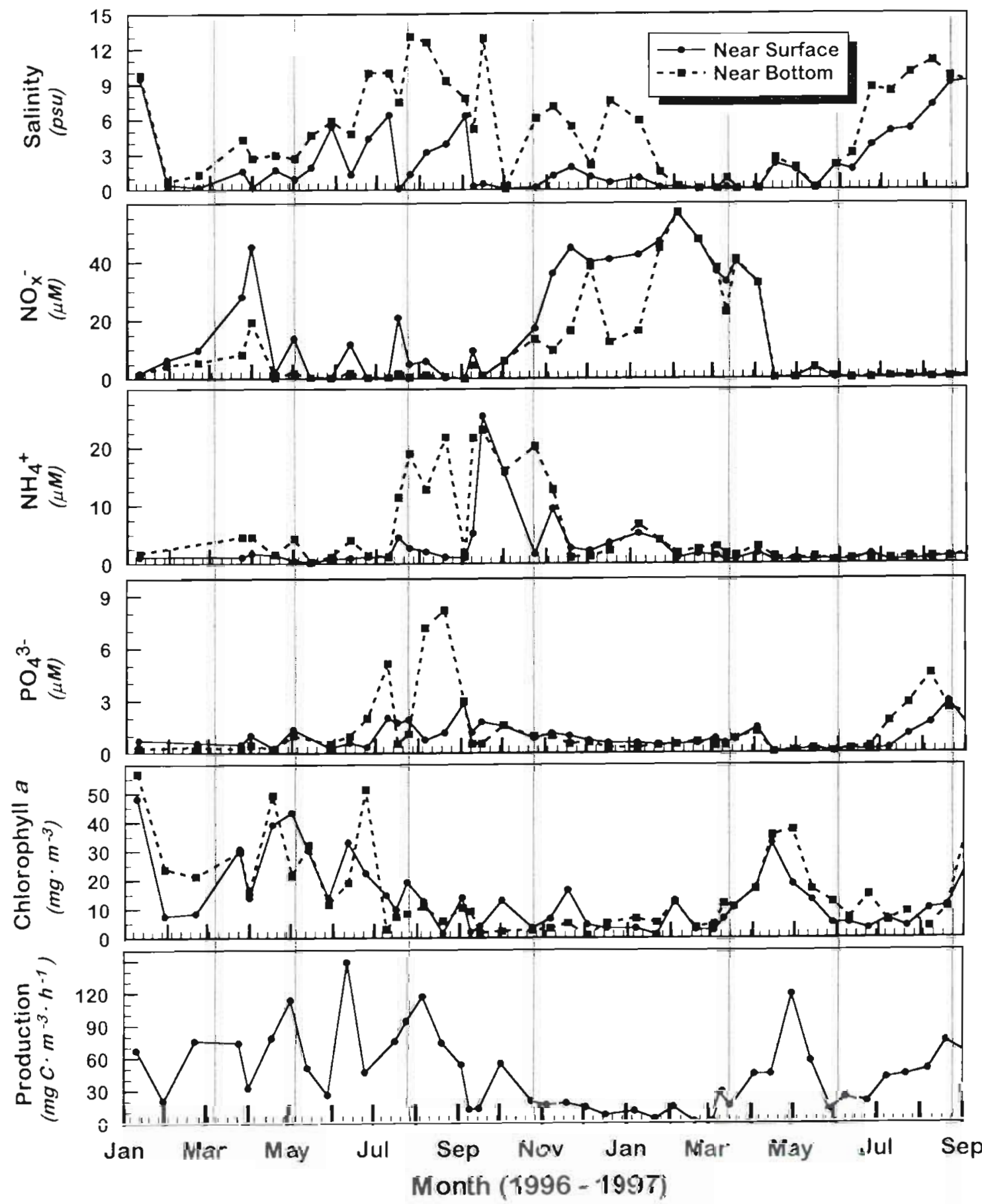

Fig. 3. Salinity, nutrients, phytoplankton biomass (chl a) and primary productivity at the water quality monitoring site (Marker 15) during the study period. Near surface values were obtained at $0.5 \mathrm{~m}$ below surface and near bottom values were $0.5 \mathrm{~m}$ above the bottom (2.5 $\mathrm{m}$ depth). Vertical lines show dates of mesocosm bioassays. $\mathrm{NO}_{x}$ - signifies the sum of $\mathrm{NO}_{3}{ }^{-}+\mathrm{NO}_{2}{ }^{-}$ 
Table 3. Results of 3 factor repeated measures ANOVA for primary productivity, photosynthetic pigments (microalgal groups), and Pfiesteria-like biflagellate zoospore cell counts for the 7 mesocosm experiments. Samples sizes (cases) are indicated in the N column. Significant responses for each of the 3 factors (mixing, sediment, nutrients) are denoted. Results of means comparisons for significant factor effects are given below each item and the highest level is indicated. For the nutrient treatment, the underline signifies homogeneous groups (not significantly different) and the group(s) with the highest mean(s) is listed first. Interaction terms were calculated for all analyses, but significant $(p<0.10)$ effects were not detected. $p<0.10$; " p $<0.01 ; \cdots p<0.001$; ns: not significant

\begin{tabular}{|c|c|c|c|c|}
\hline Variable & $\mathrm{N}$ & Mixing & Sediment & Nutrient \\
\hline $\begin{array}{l}\text { Primary productivity } \\
\text { means comparison }\end{array}$ & 252 & $\stackrel{\cdot}{\text { Mixed }}$ & ns & $\begin{array}{c}\cdots \\
\text { N NP C }\end{array}$ \\
\hline $\begin{array}{l}\text { Chlorophyll a } \\
\text { means comparison }\end{array}$ & 178 & Mixed & ns & N NPC \\
\hline $\begin{array}{l}\text { Chlorophyll } b \text { (chlorophytes) } \\
\text { means comparison }\end{array}$ & 178 & Mixed & $\mathrm{ns}$ & $\begin{array}{c}+ \\
\text { N NP C }\end{array}$ \\
\hline $\begin{array}{l}\text { Fucoxanthin (diatoms) } \\
\text { means comparison }\end{array}$ & 178 & Mixed & $\begin{array}{l}+ \\
\text { Sed. added }\end{array}$ & N NPC \\
\hline $\begin{array}{l}\text { Alloxanthin (cryptomonads) } \\
\text { means comparison }\end{array}$ & 178 & Mixed & ns & $\mathrm{ns}$ \\
\hline $\begin{array}{l}\text { Zeaxanthin (cyanobacteria) } \\
\text { means comparison }\end{array}$ & 178 & ns & ns & $\stackrel{\cdot}{\mathrm{N} N P} \mathrm{C}$ \\
\hline $\begin{array}{l}\text { Pfiesteria-like cell counts } \\
\text { means comparison }\end{array}$ & 135 & ns & ns & ns \\
\hline
\end{tabular}

biomass and productivity in the bioassays fell within the range of in situ values for the Neuse River Estuary during the study period and reflect realistic responses for natural phytoplankton communities (Fig. 3).

\section{Microalgal group-specific responses}

Chemosystematic photopigments (chlorophylls and carotenoids) characteristic for different microalgal taxa were used to assess the relative responses of phytoplankton groups to experimental manipulations. Qualitative microscopic examinations of mesocosm samples indicated that chlorophytes, diatoms, cryptomonads, and cyanobacteria were the numerically abundant algal groups present in the phytoplankton community. The relative abundance of chlorophytes, as indicated by the photopigment chl $b$, was highest in the July 1996, October 1996, and March 1997 experiments. Mixed conditions and $\mathrm{NO}_{3}{ }^{-}$additions promoted the highest chlorophyte biomass (Table 3). Diatom (fucoxanthin) abundance was higher in the sediment-amended

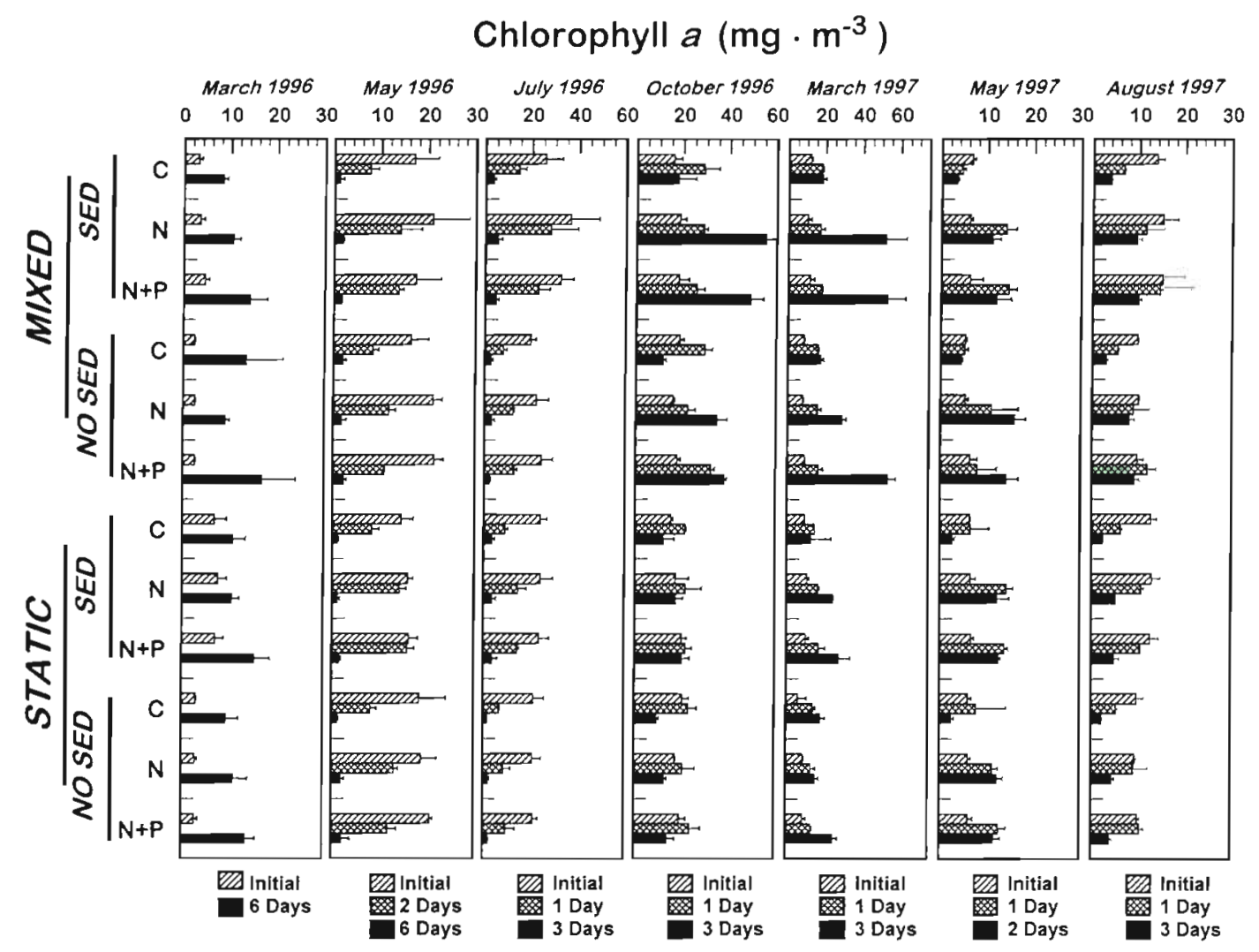

Fig. 4. Phytoplankton chlorophyll a concentrations in mesocosm bioassay tanks at specified times and experiment dates. Factor levels and treatments are detailed in Table 1 . Values are the mean \pm 1 SD for triplicate samples 
tanks and mixed tanks, possibly because of the added contribution of diatoms associated with the sediment (Table 3). Diatom response to $\mathrm{NO}_{3}{ }^{-}$additions was rapid and persistent for the duration of the incubation period. Cryptomonads (alloxanthin) were present at moderate abundances for all mesocosm assays and reached peak values in the March 1997 experiment. The mixed tanks produced significantly higher cryptomonad biomass than the static tanks. In contrast to the other algal groups, cryptomonad biomass in the nutrient-amended treatments was not significantly higher than the control treatments. Cyanobacterial abundance (zeaxanthin) was highest in the summer (July 1996. May 1997. August 1997). Nitrate-amended tanks produced significantly higher cyanobacterial biomass than control (nonamended) tanks (Table 3). For all algal groups, the $\mathrm{PO}_{4}{ }^{3-}$ additions did not elicit responses distinguishable from those of $\mathrm{NO}_{3}{ }^{-}$additions alone

\section{Pfiesteria-like zoospore responses}

The biflagellated zoospore stage of Pfiesteria-like cells was present in all mesocosm experiments (Fig. 6).
Although samples from the May 1997 experiment were examined for the presence of Pfiesteria-like cells, quantitative enumerations were not undertaken due to low cell abundances. Pfiesteria-like cell counts were highest (50 to 100 cells $\mathrm{ml}^{-1}$ ) in the July 1996 and August 1997 experiments and at densities less than 6 cells $\mathrm{ml}^{-1}$ for the other incubations. Cell counts for similar-sized phytoplankton species ranged from 1000 to 10000 cells $\mathrm{ml}^{-1}$ Pfiesteria-like zoospores therefore were a small proportion of the total number of planktonic cells. In some experiments and treatments, cell numbers increased or remained constant for the length of the incubation period (Fig. 6). Pfiesteria-like cells did not show a significant response to nutrient, sediment, or mixing treatments in any of the experiments (Table 3)

The abundance of Pfiesteria-like cells was positively correlated with phytoplankton biomass and productivity (Fig. 7). Spearman rank correlation coefficients (a non-parametric measure of the strength of the relationship between 2 variables) were calculated for Pfiesteria-like cell counts and phytoplankton groupspecific pigment concentrations. The abundance of Pfiesteria-like cells was positively correlated with pri-

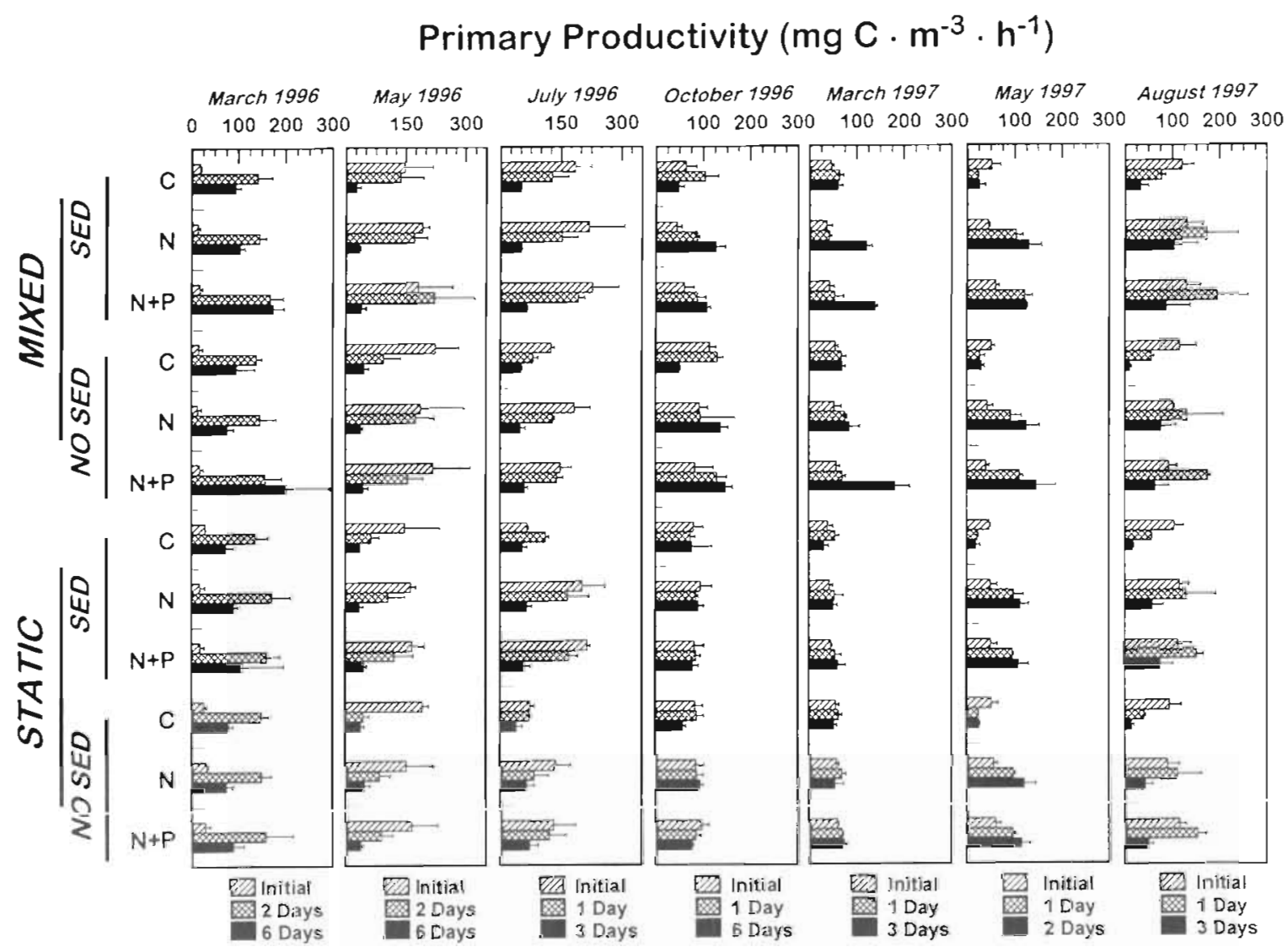

Fig. 5. Phytoplankton primary productivity in mesocosm bioassay tanks at specified times and experiment dates. Factor levels and treatments are detailed in Table 1 . Values are the mean \pm 1 SD for triplicate samples 
mary productivity, total phytoplankton biomass (chl a), cryptomonads (alloxanthin), cyanobacteria (zeaxanthin), and chlorophytes (chl b) $(\mathrm{N}=278, \mathrm{p}<0.001)$. Pfiesteria-like cell abundances reflected the relative abundance of potential phytoplankton prey species. No significant correlations $(\mathrm{p}<0.01)$ were detected for Pfiesteria-like cells and nutrient concentrations $\left(\mathrm{NO}_{3}{ }^{-}\right.$, $\mathrm{NH}_{4}{ }^{+}, \mathrm{PO}_{4}{ }^{3}$ ), salinity, $\mathrm{pH}$, or diatom biomass (fucoxanthin).

\section{DISCUSSION}

The physical, chemical, and environmental conditions in the mesocosms reflected the range of in situ water column properties in the Neuse River during the incubation period. This segment of the Neuse River has experienced fish-kills in past years (1991, 1995 to 1998) associated with the presence of Pfiesteria-like cells (Burkholder \& Glasgow 1997b). The water collection site for the mesocosm incubations was selected because of repeated instances and persistence of reported Pfiesteria fish-kills in this area. Under natural conditions, a major factor that may regulate the abundance of the heterotrophic Pfiesteria-like dinoflagel- lates is the availability of phytoplankton prey (Burkholder \& Glasgow 1995, Burkholder et al. 1995b, Fen$\sin$ 1998). Elevated nutrient concentrations have also been reported to stimulate growth of $P$. piscicida (Burkholder et al. 1992, Burkholder \& Glasgow 1995, Glasgow et al. 1995). The mesocosm bioassays were designed to provide a range of currently encountered physical, nutrient, and phytoplankton conditions to determine the potential role of key nutritive factors in regulating the abundance of the non-toxic biflagellated zoospore stage of Pfiesteria-like dinoflagellates.

The experimental approach for this project emphasized the use of natural water samples collected from the Neuse River Estuary during an 18 mo period. Since environmental conditions (weather, rainfall, salinity, etc.) in the Neuse River Estuary could not be manipulated a priori, the strategy for sampling was based on the characterization of Pfiesteria-like zoospore responses at a site where the negative impacts of this organism have been reported. Therefore, the mesocosm bioassays assessed Pfiesteria-like zoospore responses within the constraints of the natural environmental conditions experienced in the Neuse River Estuary during 1996/1997. Although salinities were relatively low $(<3$ psu) during some experiments,

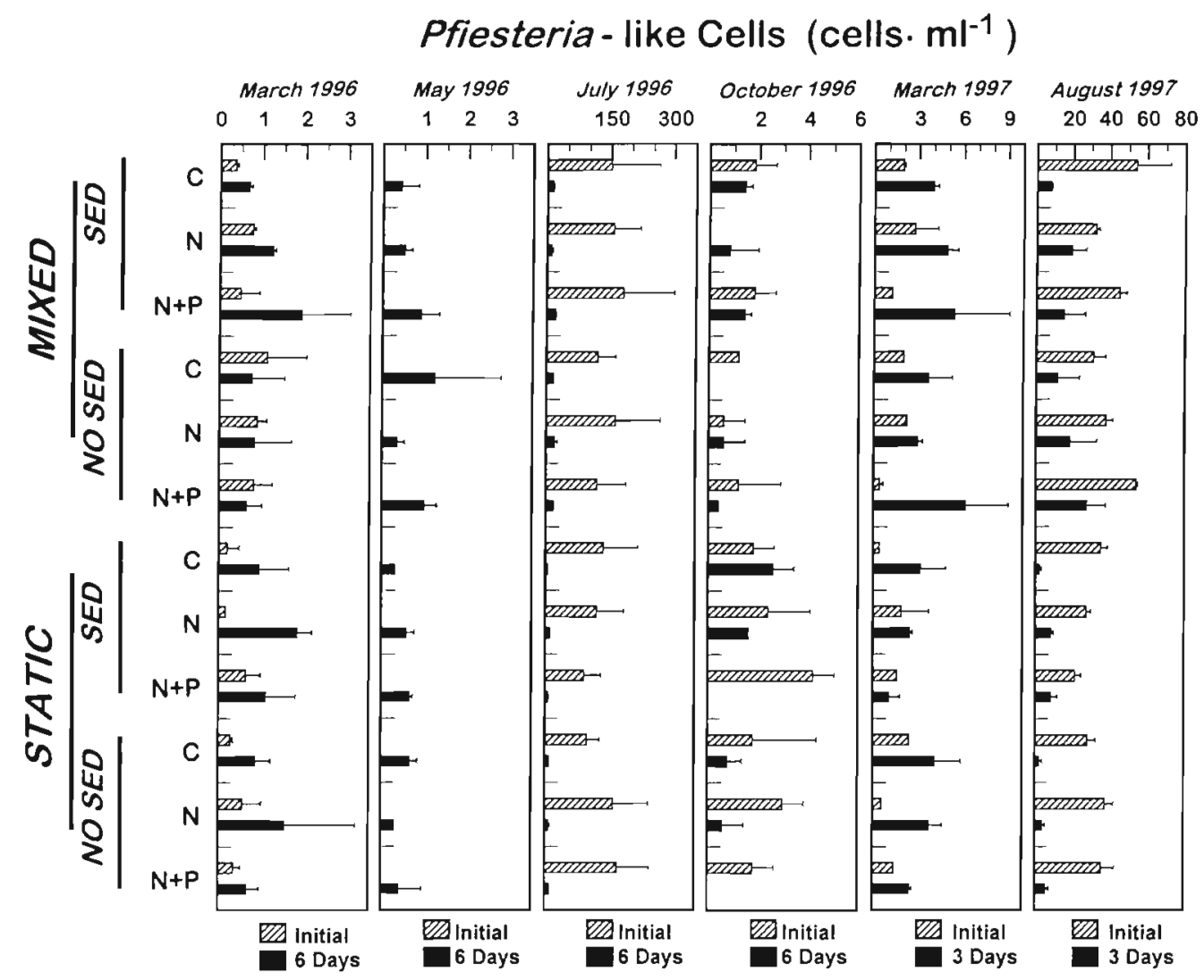

Fig. 6. Counts of Pfiesteria-like biflagellated zoospores in mesocosm bioassay tanks at specified times and experiment dates. Factor levels and treatments are detailed in Table 1 . Values are the mean $\pm 1 \mathrm{SD}$ for triplicate samples 


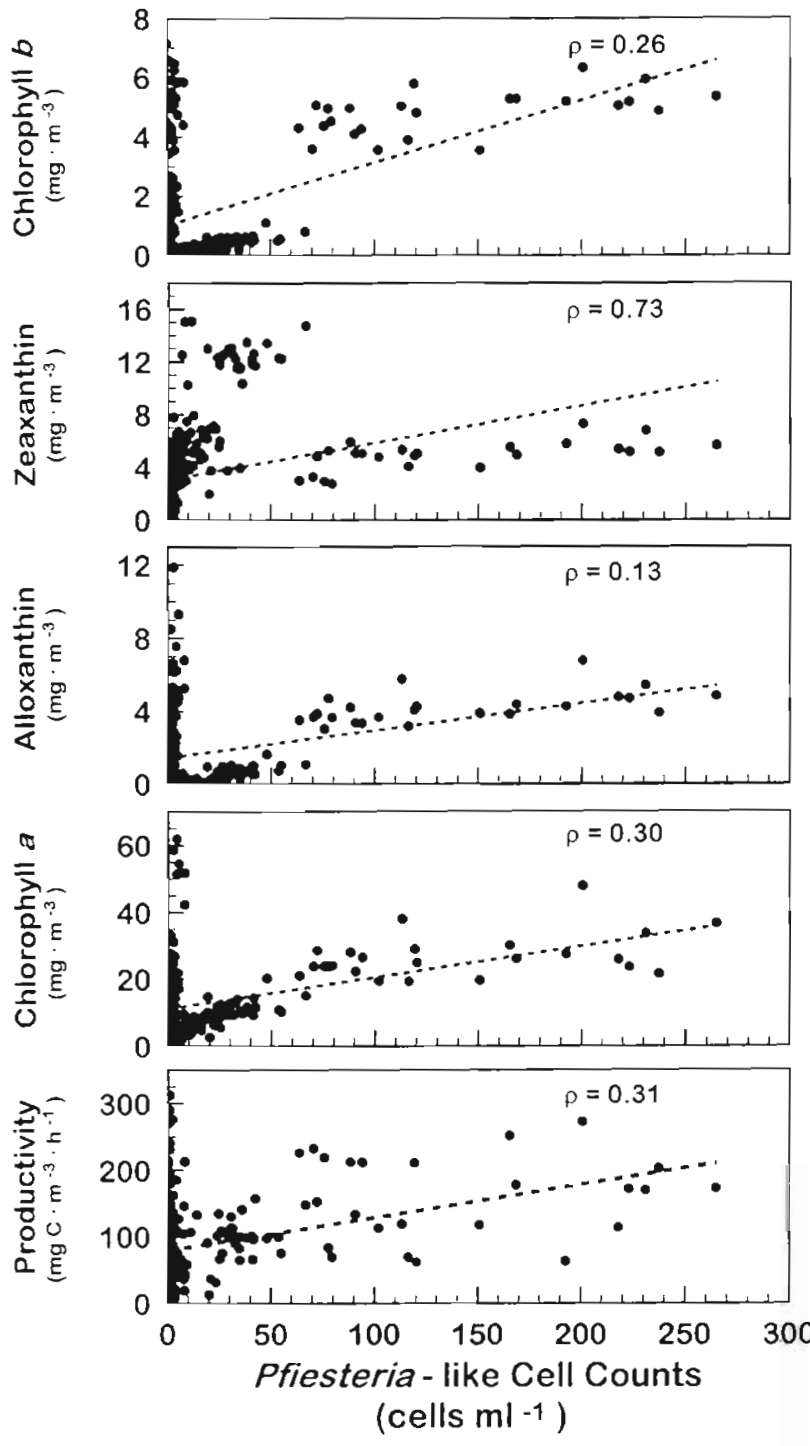

Fig. 7 Phytoplankton productivity, chlorophyll $a_{1}$ alloxanthin (cryptomonads), zeaxanthin (cyanobacteria), and chlorophyll $b$ (chlorophytes) versus Pfiesteria-like biflagellated zoospore cell counts. Dashed lines show linear trends. Spearman rank correlation coefficients $(\rho, p<0.01)$ are displayed for associations in each graph

growth and toxin production of $P$. piscicida and Pfiesteria-like zoospores have been observed in 0 psu salinity waters (Burkholder \& Glasgow 1997b) In addition, Fensin (1998) found that the highest Pfiesteria-like zoospore densities occurred at salinities between 4 and 10 pen in the Neuse Estuary in 1995. Major alterations in environmental conditions (higher salinity, warmer temperatures, calm weather, algal blooms) within the estuary could conceivably create conditions more conducive for the growth of heterotrophic dinoflagellates. However, the characterization of growth responses of Pfiesteria-like zoospores to all possible combinations of regulating factors and variables was not the objective of this project. Instead, the experimental approach relied on the manipulation of 3 selected variables (mixing, sediments, and inorganic nutrients) which were constrained and dictated by the environmental conditions within the Neuse River Estuary during the study period

The water collection methods employed in this study did not appear to damage any of the phytoplankton under examination, including fragile flagellates. Qualitative microscopic observations of pre- and post-collection water samples did not reveal any obvious differences in species composition. The abundance of Pfiesteria-like zoospores in the mesocosm tanks at the beginning of the incubations was similar to in situ abundances at the site where water was collected (Fensin 1998, E. Haugen \& P. Tester unpubl. data). At the start of the experiments, small phototrophic dinoflagellates (Katodinium rotundatum) were also present in mesocosm tanks at concentrations similar to those found in the estuary (E. Haugen unpubl. data). Similar comparisons of HPLC-derived photopigment concentrations showed that the overall phytoplankton community composition was not significantly altered by pumping and transportation. Burkholder \& Glasgow (1997b) report that turbulence slows the growth of Pfiesteria-like zoospores. The experimental manipulations in the present study included both turbulent (mixed) and non-turbulent (static) treatments to examine the role of turbulence as a regulator of zoospore abundance. The absence of a detectable difference between static and mixed treatments suggests that turbulence did not affect the abundance of Pfiesterialike zoospores

Previous experiments (including the current study) indicated that $6 \mathrm{~d}$ was sufficient to quantify and characterize Neuse River Estuary phytoplankton community responses to manipulative experiments (Paerl \& Bowles 1987, Rudek et al. 1991). The microalgal community in mesocosm tanks usually showed (1 to $3 \mathrm{~d}$ ) increases in biomass and productivity, and changes in taxonomic composition following nutrient additions. The range of phytoplankton responses in the different treatments presented an abundant and diverse food source for Pfiesteria-like zoospores. Changes in the phytoplankton community within the mesocosms closely simulated natural bloom events that occur in the Neuse River Estuary following nutrient inputs from rainfall events and subsequent diccharge (Christian et al. 1991, Rudek et al. 1991, Paerl et al. 1995, Pinckney et al. 1997, 1998). Phytoplankton community responses in the mesocosm bioassays conducted in this project were consistent with field observations in long-term studies of the Neuse River (Paerl et al. 1995, Pinckney et al. 1997, 1998). Incubations were limited to $6 \mathrm{~d}$ be- 
cause the utility of mesocosm-based experiments is compromised by atypical conditions (i.e. algal growth on tank walls, nutrient depletion, overgrazing, $\mathrm{pH}$, [DIC], etc.) in the tanks after this period.

The duration of the mesocosm incubations (6 d) should have allowed sufficient time to evaluate the growth responses of Pfiesteria-like zoospores. Heterotrophic dinoflagellate zoospores similar in size and feeding rate to $P$. piscicida typically have growth rates ( $\mu$ ) ranging from 0.5 to $1.0 \mathrm{~d}^{-1}$ (Strom 1991, Hansen 1992, Strom \& Buskey 1993, Jakobsen \& Hansen 1997). In addition, previous studies of $P$. piscicida cultures in nutrient enrichment experiments showed significant (2- to 10-fold) increases in zoospore counts within 4 to 7 d (Burkholder et al. 1992, Glasgow et al. 1995, Burkholder \& Glasgow 1997b). Under culture conditions with a suitable diet of phytoplankton prey, the growth rates of Pfiesteria-like biflagellated zoospores obtained from the present study were ca 0.8 to $1.0 \mathrm{~d}^{-1}$ (P. Tester $\&$ E. Haugen unpubl. data). Increases in the abundance of Pfiesteria-like zoospores in some experimental bioassays (March, May 1996, and March 1997) clearly indicate that the duration of the mesocosm experiments was adequate for assessing responses of zoospores to experimental conditions. The differences in responses between culture and mesocosm conditions suggest that factors other than nutrients or shortterm increases in phytoplankton prey species may regulate the natural abundance of Pfiesteria-like biflagellated zoospores.

The phytoplankton community responses to the manipulated variables showed that, in general, biomass and productivity were consistently $\mathrm{N}$ limited in all experiments. The inability to demonstrate different responses for the $\mathrm{NO}_{3}{ }^{-}$and the $\mathrm{NO}_{3}{ }^{-}+\mathrm{PO}_{4}{ }^{3}$ treatments suggested that $\mathrm{P}$ was not limiting for phytoplankton growth. These results support previous nutrient bioassay and uptake kinetics results for Neuse River Estuary phytoplankton conducted during the past decade (Paerl 1987. Stanley 1988, Rudek et al. 1991, Boyer et al. 1993, 1994, Paerl et al. 1995). The duration of the mesocosm bioassay incubations ( $6 \mathrm{~d}$ ) was sufficient to allow at least a 3-fold increase in phytoplankton biomass. Similarly, phytoplankton communities in some mesocosm tanks bloomed following nutrient additions and subsequently 'crashed' when nutrients became limiting.

Chlorophytes, diatoms, and cyanobacteria exhibited significant increases in biomass in response to $\mathrm{NO}_{3}{ }^{-}$ additions. Phosphate $\left(\mathrm{PO}_{4}{ }^{3-}\right)$ additions did not seem to influence the abundance of any single microalgal group. Diatoms responded rapidly (within $1 \mathrm{~d}$ ) to $\mathrm{NO}_{3}{ }^{-}$ additions and biomass was consistently highest in the mixed tanks. The mixed tanks also promoted higher chlorophyte and cryptomonad biomass. The sedimentaddition treatments supported higher diatom biomass but did not have a significant effect on other algal groups, total biomass ( $\mathrm{chl}$ a), or primary productivity. Collectively, these data suggest that the phytoplankton community exhibited higher growth under mixed conditions and elevated $\mathrm{NO}_{3}{ }^{-}$concentrations (Pinckney et al. 1999).

The abundance of Pfiesteria-like flagellated zoospores in the sediment-amended tanks did not differ from tanks without sediment additions. These results suggest that the presence of sediments from a fish-kill area had no significant short-term impact on the abundance of Pfiesteria-like zoospores. In contrast, diatom biomass was significantly higher in the mesocosms that received sediment additions. Diatoms are a major component of benthic microalgae in shallow $i<2 \mathrm{~m})$ Neuse River sediments (Rizzo et al. 1992, Pinckney \& Zingmark 1993). Resuspension of benthic or deposited diatoms and subsequent growth resulting from the sediment additions could explain the higher diatom biomass in the tanks receiving sediments.

The mesocosm bioassay array provided suitable physical-chemical conditions and prey species for Pfiesteria-like cells. Pfiesteria-like zoospores were always present in the initial incubation water and persisted for the duration of the incubations. Increases in cell numbers suggest that water collection and incubation conditions were not detrimental for growth of heterotrophic dinoflagellates or phytoplankton. Heterotrophic dinoflagellates, including Pfiesterialike zoospores, graze on a variety of phytoflagellates (chlorophytes, cryptomonads, prymnesiophytes, other dinoflagellates) and coccoid cyanobacteria (Fields \& Rhodes 1991, Hansen 1991, Burkholder \& Glasgow 1995, 1997b, Mallin et al. 1995). Taxa for all of these algal groups were present in a range of concentrations, providing a rich and diverse food source for Pfiesterialike zoospores. In some experiments, there were detectable increases in the number of Pfiesteria-like cells, indicating that the mesocosms were capable of supporting and enhancing the growth of heterotrophic dinoflagellates. Zooplankton and ciliate grazers, which readily consume Pfiesteria-like zoospores (Burkholder \& Glasgow 1995, 1997b, Mallin et al. 1995), may play a major role in regulating the abundance of heterotrophic dinoflagellates and could explain the disappearance/low cell counts observed in some experiments (Hansen 1991, Jakobsen \& Hansen 1997). Among the 3 manipulated factors in the experiment, there was no significant positive or negative effect on the abundance of Pfiesteria-like biflagellated zoospores. The absence of a significant Pfiesteria-like cell response to the nutrient treatments suggests that $\mathrm{NO}_{3}{ }^{-}$ and $\mathrm{PO}_{4}{ }^{3-}$ concentrations similar to those encountered in situ in natural environments do not increase the abundance of Pfiesteria-like biflagellated zoospores. 
Although cell numbers were low throughout the experimental period, the seasonal abundance of Pfiesteria-like flagellated zoospores was positively correlated with phytoplankton biomass and productivity. Comparisons with the relative abundance of other microalgal groups suggest that Pfiesteria-like zoospore counts tracked phytoflagellates (chlorophytes and cryptomonads) and cyanobacteria, which are known prey items for heterotrophic dinoflagellates (Burkholder \& Glasgow 1997b). Fensin (1998) also found that Pfiesterialike zoospores were positively correlated with phytoplankton biomass (as chl a) and algal prey species in the Neuse Estuary in 1994/1995. In our study, there was no significant correlation between Pfiesteria-like zoospores and diatom biomass. The zoospore stage of $P$. piscicida feeds on algal cells using a peduncle to ingest cellular contents (Spero 1981, Steidinger et al. 1996a, Burkholder \& Glasgow 1997a). Diatoms, which have a silica frustule, may be protected from this mode of grazing The Neuse River Estuary experiences large blooms of phytoflagellates and cyanobacteria that closely follow discharge-related nutrient pulsing events in the spring and summer (Mallin et al. 1993, Mallin 1994, Paerl et al. 1995). These blooms may provide a periodic, abundant food source that supports the growth and abundance of Pfiesteria-like and other heterotrophic dinoflagellates. Carbon loading by phytoplankton production followed by bloom senescence promotes oxygen depletion (Paerl \& Pinckney 1996). Therefore, the co-occurrence of high abundances of Pfiesteria-like dinoflagellates and hypoxia/anoxia may be explained by nutrient-driven phytoplankton bloom dynamics in the Neuse River Estuary

The absence of significant responses of Pfiesterialike zoospores to the manipulated variables in the mesocosm bioassays (Table 3 ) and the significant nonparametric correlations between Pfiesteria-like zoospore counts and phytoplankton groups (Fig. 7) may seem contradictory. However, these results provide valuable insight into other factors that may regulate the abundance of Pfiesteria-like zoospores in this estuary. The mesocosm bioassays simulated short-term bloom events that frequently occur in the Neuse River Estuary in response-pulsed nutrient inputs (Pinckney et al. 1997). This estuary also experiences chronic high abundances of some phytoplankton groups (cryptomonads, cyanobacteria, chlorophytes) during summer months (Pinckney et al. 1997, 1998). The correlations hefween the ahundanre of Pfiesteria-like zoospores and different phytoplankton groups can be attributed to measurements oblained at the start (time 0 ) of the mesocosm bioassays. Therefore, these correlations may reflect longer-term (months) changes in the seasonal abundance of Pfiesteria-like zoospores that closely track seasonal changes in phytoplankton abundance and composition (Fensin 1998). Another equally plausible explanation is that the abundances of phytoplankton and Pfiesteria-like zoospores are autocorrelated. For example, secondary factors (meteorological conditions, temperature, salinity, microheterotroph grazers, etc.) may regulate the seasonal abundance of both phytoplankton and heterotrophic dinoflagellates.

\section{Implications for nutrient management}

Results indicate that a consistently low density ( $<100$ cells $\mathrm{ml}^{-1}$ ) of Pfiesteria-like cells were present throughout the 18 mo sampling and mesocosm bioassay period in a location of the Neuse River Estuary which, over the past decade, has exhibited symptoms of accelerating eutrophication, including increased frequencies, magnitudes, and duration of phytoplankton blooms, dissolved oxygen depletion, and fish-kills. Neuse Estuary phytoplankton production and bloom dynamics are dominated by several species of photosynthetic dinoflagellates (e.g. Heterocapsa triquetra, Gymnodinium spp.), cryptomonads (Cryptomonas spp., Rhodomonas spp.), and coccoid cyanobacteria (Synechococcus spp., Synechocystis spp.), with diatoms and chlorophytes present in non-bloom proportions (Mallin 1994, Pinckney et al. 1998, 1999). While Pfiesteria-like cells did not show direct or indirect responses to nutrient enrichment, they did follow seasonal trends in phytoplankton production in this estuary, suggesting that the source of organic nutrition supporting Pfiesteria-like cells is likely phytoplankton based.

Clearly, nutrient input reduction is the only manageable option for stemming and potentially reversing water quality degradation of the Neuse and neighboring estuarine tributaries (Tar-Pamlico, Roanoke, Chowan) of the greater Albemarle-Pamlico Sound system. Targeting nutrient reductions at those phytoplankton taxa dominating primary production and the eutrophication process seems logical, if not imperative, since these taxa are the key source of organic matter supporting and exacerbating the unwanted consequences of eutrophication (i.e. hypoxia, toxic algal species, fish-kills, etc. ), including Pfiesteria-like cells. Since Pfiesteria-like zoospores showed insignificant direct and indirect responses to enrichment of nutrients closely associated with human activities and sources in the Neuse Basin (inorganic $N$ and $P$ ), while the main bloom-forming phytoplanton did, it socms prudent, and potentiully most effective, that nutrient input constraints focus on the main 'players' driving the eutrophication process. In all likelihood, nutrient-reduction controlled growth and bloom constraints on taxa dominating the production process will translate into improved water quality conditions throughout the food web. 
Acknowledgements. Dr Richard G. Zingmark (University of South Carolina, Columbia, SC) prepared samples for SEM and provided dinoflagellate species identifications. Other project participants included students and technicians: J. Fear, M. Go, K. Howe, L. Kelly, S. Kucera, T Nanni, J. Olson, B. Peierls, M. Piehler, T Steppe, J. Swistak, S. Thompson, D. Whitall, and P. Wyrick. This research was funded by the North Carolina Sea Grant Program.

\section{LITERATURE CITED}

Boyer J, Christian R, Stanley D (1993) Patterns of phytoplankton primary productivity in the Neuse River Estuary. Mar Ecol Prog Ser 97:287-297

Boyer J, Stanley D, Christian R (1994) Dynamics of $\mathrm{NH}_{4}{ }^{+}$and $\mathrm{NO}_{3}{ }^{-}$uptake in the water column of the Neuse River estuary, North Carolina. Estuaries 17:361-371

Burkholder J, Glasgow $\mathrm{H}$ (1995) Interactions of a toxic estuarine dinoflagellate with microbial preclators and prey. Arch Protistenkd 145:177-188

Burkholder J, Glasgow H (1997a) Trophic controls on stage transformations of a toxic ambush-predator dinoflagellate. J Eukaryot Microbiol 44:200-205

Burkholder J, Glasgow H (1997b) Pfiesteria piscicida and other Pfiesteria-like dinoflagellates: Behavior, impacts, and environmental controls. Limnol Oceanogr 42: 1052-1075

Burkholder J, Noga E, Hobbs C, Glasgow H (1992) New 'phantom' dinoflagellate is the causative agent of major estuarine fish kills. Nature 358:407-410

Burkholder J, Glasgow H, Steidinger K (1995a) Stage transformations in the complex life cycle of an ichthyotoxic 'ambush-predator' dinoflagellate. In: Lassus $\mathrm{P}$, Arzul $\mathrm{G}$, Erard E, Gentien P, Marcaillou C (eds) Harmful marine algal blooms. Lavoisier, Paris, p 567-572

Burkholder J, Glasgow H, Hobbs C (1995b) Fish kills linked to a toxic ambush-predator dinoflagellate: distribution and environmental conditions. Mar Ecol Prog Ser 124:43-61

Christian R, Bryant W, Stanley D (1986) The relationship between river flow and Microcystis aeruginosa blooms in the Neuse River, North Carolina. WRRI Report No. 223, UNC Water Resources Research Institute, Raleigh, NC

Christian R, Boyer J, Stanley D (1991) Multi-year distribution patterns of nutrients within the Neuse River Estuary. Mar Ecol Prog Ser 71:259-274

Fensin E (1998) Seasonal population dynamics of the phytoplankton community, and of Pfiesteria piscicida/Pfiesterialike dinoflagellates in the mesohaline Neuse Estuary, North Carolina. M Sci thesis, North Carolina State University, Raleigh, NC

Fields S, Rhodes R (1991) Ingestion and retention of Chroomonas spp. (Cryptophyceae) by Gymnodinium acidotum (Dinophyceae). J Phycol 27:525-529

Glasgow H, Burkholder J, Schmechel D, Tester P, Rublee P (1995) Insidious effects of a toxic estuarine dinoflagellate on fish survival and human health. $J$ Toxicol Environ Health 46:501-522

Hansen P (1991) Quantitative importance and trophic role of heterotrophic dinoflagellates in a coastal pelagial food web. Mar Ecol Prog Ser 73:253-261

Hansen P (1992) Prey size selection, feeding rates and growth dynamics of heterotrophic dinoflagellates with special emphasis on Gyrodinium spirale. Mar Biol 114:327-334

Jakobsen H, Hansen P (1997) Prey size selection, grazing and growth response of the small heterotrophic dinoflagellate Gymnodinium sp. and the ciliate Balanion comatum-a comparative study. Mar Ecol Prog Ser 158:75-86
Jeffrey S, Mantoura R, Wright S (eds) (1997) Phytoplankton pigments in oceanography: guidelines to modern methods. UNESCO Publishing, Paris

Landsberg J, Steidinger K, Blakesley B (1995) Fish-killing dinoflagellates in a tropical marine aquarium. In: Lassus $P$, Arzul G, Erard E, Gentien P, Marcaillou C (eds) Harmful marine algal blooms. Lavoisier, Paris, p 65-70

Lewitus A, Jesien R, Kana T, Burkholder J, May E (1995) Discovery of the 'phantom' dinoflagellate in Chesapeake Bay. Estuaries 18:373-378

Mallin M (1994) Phytoplankton ecology of North Carolina estuaries. Estuaries 17:561-574

Mallin M, Paerl H, Rudek J, Bates P (1993) Regulation of estuarine primary production by watershed rainfall and river. flow. Mar Ecol Prog Ser 93:199-203

Mallin M. Burkholder J, Larsen L, Glasgow H (1995) Response of two zooplankton grazers to an ichthyotoxic estuarine dinoflagellate. J Plankton Res 17:351-363

Mantoura $R$, Llewellyn $C$ (1983) The rapid determination of algal chlorophyll and carotenoid pigments and their breakdown products in natural waters by reverse-phase high-performance liquid chromatography. Anal Chim Acta 151:297-314

Miller C, Judkins D (1981) Design of pumping systems for zooplankton sampling, with descriptions of two highcapacity samplers for coastal studies. Biol Oceanogr 1 29-56

Millie D, Paerl H, Hurley J (1993) Microalgal pigment assessments using high-performance liquid chromatography: a synopsis of organisma] and ecological applications. Can J Fish Aquat Sci 50:2513-2527

Neter J, Wasserman W, Kutner M (1985) Applied linear statistical models. RD Irwin Inc, Homewood, IL

Noga E, Khoo L, Stevens J, Fan Z, Burkholder J (1996) Novel toxic dinoflagellate causes epidemic disease in estuarine fish. Mar Pollut Bull 32:219-224

Paerl H (1983) Factors regulating nuisance blue-green algal bloom potentials in the lower Neuse River. WRRI Report No. 177, UNC Water Resources Research Institute, Raleigh, $\mathrm{NC}$

Paerl H (1987) Dynamics of blue-green algal (Microcystis aeruginosa) blooms in the lower Neuse River, NC: causative factors and potential controls. WRRI Report No. 229, UNC Water Resources Research Institute, Raleigh, NC

Paerl H, Bowles N (1987) Dilution bioassays: their application to assessments of nutrient limitation in hypereutrophic waters. Hydrobiologia 146:265-273

Paerl H, Pinckney J (1996) Hypoxia, anoxia, and fish kills in the Neuse Estuary: why was 1995 a bad year? UNC Sea Grant Program, Waterwise 4(2):1-2

Paerl H, Mallin M, Donahue C, Go M, Peierls B (1995) Nitrogen loading sources and eutrophication of the Neuse River Estuary, NC: direct and indirect roles of atmospheric deposition. WRRI Report No. 291, UNC Water Resources Research Institute, Raleigh, NC

Paerl H, Pinckney J, Fear J, Peierls B (1998) Ecosystem responses to internal and watershed organic matter loading: consequences for hypoxia and fish kills in the eutrophying Neuse River Estuary, North Carolina. Mar Ecol Prog Ser 166:17-25

Pinckney J, Zingmark R (1993) Biomass and production of benthic microalgal communities in five typical estuarine habitats. Estuaries 16:887-897

Pinckney J, Millie D, Howe K, Paerl H, Hurley J (1996) Flow scintillation counting of ${ }^{14} \mathrm{C}$-labeled microalgal photosynthetic pigments. J Plankton Res 18:1867-1880 
Pinckney J, Millie D, Vinyard B, Paerl H (1997) Environmental controls of phytoplankton bloom dynamics in the Neuse River Estuary (North Carolina, USA). Can J Fish Aquat Sci 54:2491-2501

Pinckney J, Paerl H, Harrington M, Howe K (1998) Annual cycles of phytoplankton community structure and bloom dynamics in the Neuse River Estuary, NC (USA). Mar Biol 131:371-382

Pinckney J, Paerl H, Harrington M (1999) Phytoplankton community growth rate responses to nutrient pulses in variable estuarine environments. J Phycol (in press)

Rizzo W, Lackey G, Christian R (1992) Significance of euphotic, subtidal sediments to oxygen and nutrient cycling in a temperate estuary. Mar Ecol Prog Ser 86: 51-61

Rowan K (1989) Photosynthetic pigments of the algae. Cambridge University Press, Cambridge

Rudek J, Paerl H, Mallin M. Bates P (1991) Seasonal and hydrological control of phytoplankton nutrient limitation in the lower Neuse River Estuary, North Carolina. Mar Ecol Prog Ser 75:133-142

Spero H (1981) Phagotrophy in Gymnodinium fungiforme (Pyrrhophyta): the peduncle as an organelle of ingestion. J Phycol 18:354-360

Stanley D (1988) Historical trends in nutrient loading to the Neuse River Estuary, NC. In: Lyke W, Hoban $\Upsilon$ (eds) Proc Am Water Resources Assoc Symp on Coastal Water Resources, AWRA Tech Publ Ser TPS-88-1, AWRA Bethesda, MD, p 155-164

Steidinger K, Tangen K (1997) Dinoflagellates. In: Tomas C (ed) Identifying marine phytoplankton. Academic Press, New York, p 387-584

Steidinger K, Burkholder J, Glasgow H, Hobbs C, Garret J, Truby E, Noga E, Smith S (1996a) Pfiesteria piscicida gen. et sp. nov. (Pfiesteriaceae fam. nov.), a new toxic dinofla-

Editorial responsibility: Otto Kinne (Editor), Oldendorf/Luhe, Germany gellate with a complex life cycle and behavior. J Phycol $32: 157-164$

Steidinger K, Landsberg J, Truby E, Blakesley B (1996b) The use of scanning electron microscopy in identifying small 'gymnodinioid' dinoflagellates. Nova Hedwigia 112 $415-422$

Strom S (1991) Grazing and growth rates of the herbivorous dinoflagellate Gymnodinium sp. from the subarctic Pacific Ocean. Mar Ecol Prog Ser 78: 103-113

Strom S, Buskey E (1993) Feeding, growth, and behavior of the thecate heterotrophic dinoflagellate Oblea rotunda Limnol Oceanogr 38:965-977

Tester P, Geesey M, Guo C, Paerl H, Millie D (1995) Evaluating phytoplankton dynamics in the Newport River estuary (North Carolina, USA) by HPLC-derived pigment profiles. Mar Ecol Prog Ser 124:237-245

Truby E (1997) Preparation of single-celled marine dinoflagellates for electron microscopy. Microsc Res Tech 36: $337-340$

Utermöhl H (1931) Neue Wege in der quantitativen Erfassung des Planktons (mit besonderer Berücksichtigung des Ultraplanktons). Verh Int Ver Theor Angew Limnol 5: 567-596

Utermöhl H (1958) Zur Vervollkommnung der quantitativen Phytoplankton-Methodik. Mitt Int Ver Theor Angew Limnol 9:1-38

van Heukelem L, Lewitus A, Kana T, Craft N (1994) Improved separations of phytoplankton pigments using temperature-controlled high performance liquid chromatography. Mar Ecol Prog Ser 114:303-313

Wright S, Jeffrey S, Mantoura R, Llewellyn C, Bjørnland T, Repeta D, Welschmeyer N (1991) An improved HPLC method for the analysis of chlorophylls and carotenoids from marine phytoplankton. Mar Ecol Prog Ser 77 : $183-196$

Submitted: January 4, 1999; Accepted: August 13, 1999 Proofs received from author(s): December 28, 1999 